\title{
'I do not like her going to the shelter': Stories on gendered disaster (im)mobility and wellbeing loss in coastal Bangladesh
}

\author{
Dr Sonja Ayeb-Karlsson ${ }^{1,2}$ \\ ${ }^{1}$ University of Sussex, Falmer Brighton, UK \\ ${ }^{2}$ United Nations University - Institute for Environment and Human Security, Bonn, Germany
}

Corresponding author: Dr Sonja Ayeb-Karlsson (http://orcid.org/0000-0001-6124-2730)

Address: Arts Road Building C, University of Sussex, Brighton, BN1 9SJ, UK

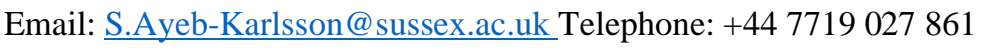

\begin{abstract}
Dr Sonja Ayeb-Karlsson
Dr Sonja Ayeb-Karlsson researches (im)mobility, migration, health and mental wellbeing in the context of climate change. Her research combines quantitative and qualitative methods such as Q, survey design, storytelling methodology and discourse analysis. She is a Senior Researcher at UNUEHS, part of Lancet Countdown's WG1 and WG2, a University of Sussex Lecturer and Co-Investigator on the Sussex Sustainability Research Programme and an editorial board member of Climate and Development.
\end{abstract}

Address: Arts Road Building C, University of Sussex, Brighton, BN1 9SJ

Email: $\underline{\text { S.Ayeb-Karlsson@sussex.ac.uk }}$

\begin{abstract}
The literature body on cyclone strikes in Bangladesh suggests that people sometimes fail to evacuate, and that more women than men have died in past disasters. People's reasoning and decision-making leading up to their disaster (im)mobility are strongly embedded in social structures such as gender systems. Subjective non-evacuation behaviours are founded in collective understandings and reproductions of social values. People's perceptions around these values therefore offer important empirical evidence that helps us understand who, how and why some people end up immobile or 'trapped' when disaster strikes. This study builds on individual and collective unstructured people-centred storytelling sessions and discourse analysis. The storytelling study captured rich empirical insights around the notions of disaster (im)mobility, and their links to the existing power and gender systems. Three thematic areas were identified including; safe and unsafe spaces for women and men, female and male knowledge, and male and female experiences of 'internal damages', trauma and mental ill-health. The insightful storylines of socially immobilising attitudes can support building robust climate policy and DRR frameworks that better protect our most vulnerable people across the globe.
\end{abstract}

Keywords: disasters, (im)mobility, gender, mental health, Non-Economic Loss and Damage, non-evacuation behaviour, Trapped Populations 


\section{Acknowledgements}

First and foremost, I would like to thank the people who opened their homes and dedicated their time to this research. I also thank Prof Dominic Kniveton at University of Sussex and Mr Terry Cannon at Institute of Development Studies for their constructive comments and for our extensive critical conversations leading up to the improvement of the manuscript. I am grateful for the heartfelt support from my Gibika project team, and especially Mr Istiakh Ahmed for all the time we spent in field. I also thank our colleagues at Munich Re Foundation, in particular Mr Thomas Loster and Mr Christian Barthelt. I am also appreciative of the efforts invested by additional colleagues at the International Centre for Climate Change and Development, Institute of Development Studies, University of Sussex, UN University's Institute for Environment and Human Security and Durham University, and particularly Dr Christopher D. Smith, Dr Andrew Baldwin and Prof David Ockwell, who in one way or another have supported the article's development. I also thank the Lancet Countdown network for rich and insightful discussions during our working group meetings. 


\section{Introduction}

People in coastal Bangladesh have expressed distress and fear around the uncertainty of living in cyclone ${ }^{1}$ affected areas (Mallick and Vogt 2012; Ayeb-Karlsson 2020a). This deep uncertainty includes not knowing whether a cyclone will strike, when the disaster will strike, its intensity as well as its impact upon people and their loved ones. Coastal Bangladesh merely represents one area in the world where people have had to learn to live with cyclones. The process of a depression turning into a storm or cyclone, helps portray what this environmental uncertainty means for people living here. Generally a wind speed below approximately 60$70 \mathrm{~km} / \mathrm{h}$ is called a tropical depression, wind speeds above this to about $100-120 \mathrm{~km} / \mathrm{h}$ are referred to as tropical storms, while wind speeds above $100-120 \mathrm{~km} / \mathrm{h}$ become tropical cyclones. On average, the Bay of Bengal experiences 13 depressions each year. That is 13 times per year that people prepare themselves emotionally for the possibility of facing a cyclone. People have had to learn how to live with the depressions, storms, and the risk of them turning into cyclones. Not all of the cyclones in the Bay of Bengal strike Bangladesh, and one single cyclone never hits the entire coast. However, cyclones do regularly wreak havoc along the coast of Bangladesh (Penning-Rowsell et al. 2013; Ayeb-Karlsson 2020a).

Over the last 200 years, about 70 cyclones have struck Bangladesh reportedly killing about a million people in total. The two deadliest were the 1970 Bhola cyclone, killing about half a million people, and the 1991 Gorky cyclone causing the death of over hundred thousand (Chowdhury et al. 1993; Penning-Rowsell et al. 2013; Alam and Rahman 2014). There are still ambiguities around the death tolls as people dying after the strike, for example, due to the lack

\footnotetext{
${ }^{1}$ Tropical cyclonic storms have different names depending on where they are formed. The scales determining the windspeed of a depression, storm and cyclone also differ. Storms formed in the Atlantic Ocean are called hurricanes, storms in the Pacific Ocean are named typhoons and cyclones are storms formed in the Indian Ocean.
} Since this study focuses on Bangladesh, the term cyclones will be used throughout the article. 
of water, food or medical attention, were not included in the casualties. A common trend within disaster impacts is that women and children are among the most affected. The increased vulnerability of these groups is often inherited in social and structural inequalities and power systems (Chowdhury et al. 1993; Cutter 1995, 2017; Jordan 2018; Ayeb-Karlsson et al. 2019a; Watts et al. 2019). This also aligns with the critical conceptualisation where hazards first become disasters once negatively impacting vulnerable populations. In this way, disaster severity is a reflection of location, intensity and amount of vulnerable people impacted (Blaikie et al. 1994; Oliver-Smith et al. 2017; Ayeb-Karlsson et al. 2019a; Kelman 2020).

This study investigates how social values and reasoning can result in gendered disaster immobility. People's gender-roles (women's and men's) can provide insightful explanations to the notions of the collective and subjective disaster immobility. As noted by several immobility scholars, the links between immobility or 'trapped' populations and people's choices to stay or move away from environmental hazards are complex (Black et al. 2013; Black and Collyer 2014; Ayeb-Karlsson et al. 2018, 2020). The Trapped Populations ${ }^{2}$ concept, referring to people desiring but being unable to move away from risky locations and situations, has recently triggered a growing literature body that conceptualises immobility. This literature analyses the broader financial, political, social, and psychological forces resulting in non-migration behaviour (Black et al. 2011; Ayeb-Karlsson et al. 2018, 2020; Nawrotzki and DeWaard 2018; Blondin 2020), and non-evacuation behaviour (Penning-Rowsell et al. 2013; Logan et al. 2016;

\footnotetext{
${ }^{2}$ In this article, Trapped Populations or Non-Economic Loss and Damage (in capital letters) are used to refer to the concepts (noun); trapped or lost and damaged (no capital letter) are used to refer to the verbs e.g. the action of being rendered immobile or an element being lost or damaged (verb); and finally, 'trapped' is used to refer to the adjective e.g. when a person is labelled as being thus, while 'lost' or 'damaged' is used to describe when a non-economic element is lost or damaged (adjective).
} 
McCaughey et al. 2018; Ayeb-Karlsson 2020a). Until recently, there has been an overrepresentation of 'trapped 'studies investigating financial and geographical non-migration, but over the last few years more critical studies elaborating around social and psychological immobility (including gendered immobility) are gaining ground (Mata-Codesal 2015; Bhatta et al. 2016; Ayeb-Karlsson et al. 2020; Ayeb-Karlsson 2020a, 2020b). This aligns with the extended focus on more people-centred climate change research investigating social, psychological and emotional impacts of environmental stress (Ayeb-Karlsson et al. 2016, 2019b, 2020; Tebboth et al 2019; Conway et al. 2019; Brown et al. 2019), as well as the conceptual creation and development of Non-Economic Loss and Damage within climate policy (UNFCCC 2013; Boyd et al 2017; Tschakert et al. 2019, Ayeb-Karlsson 2020b).

Comprehensive empirical evidence on gendered disaster immobility can help save lives and support a more sustainable future through the protection of vulnerable populations living with hazards. Disaster Risk Reduction (DRR) scholars have long encouraged more critical investigations of social gender-vulnerability (Rivers 1982; Fothergill 1996; Enarson 1998; Alam and Rahman 2014). Gender studies often investigate poor and victimised women in 'developing countries' where vulnerabilities are rooted in more than linear gender structures including class and race systems (Elliott and Pais 2006; Thiede and Brown 2013; Oliver-Smith et al. 2017). Storylines around the poor, victimised developing south woman also reinforces post-colonial climate change and vulnerability discourses (Cannon and Müller-Mahn 2010; Felli and Castree 2012; Oliver-Smith 2016; Baldwin 2016). This empirical storytelling study on gendered (male and female) disaster immobility in Bangladesh will in this way help wide the DRR literature. More local insights around socio-cultural perceptions and values, such as the evidence captured in this study, will improve the effectiveness of DRR and climate policy frameworks so as to better protect vulnerable people living in environmentally risky locations. 


\section{A review of the disaster immobility literature}

The Trapped Population's framework was proposed by the Foresight Report and linked immobility to financial, social and political capitals (Fig. 1). Poor people were conceptualised to be less able to move although often inhabiting greater desires to leave. This was described as facing a double set of risks - not only were poor people more vulnerable but also less able to escape environmental threats (Foresight 2011; Black et al. 2013).

\section{Fig. 1 Trapped Population model}

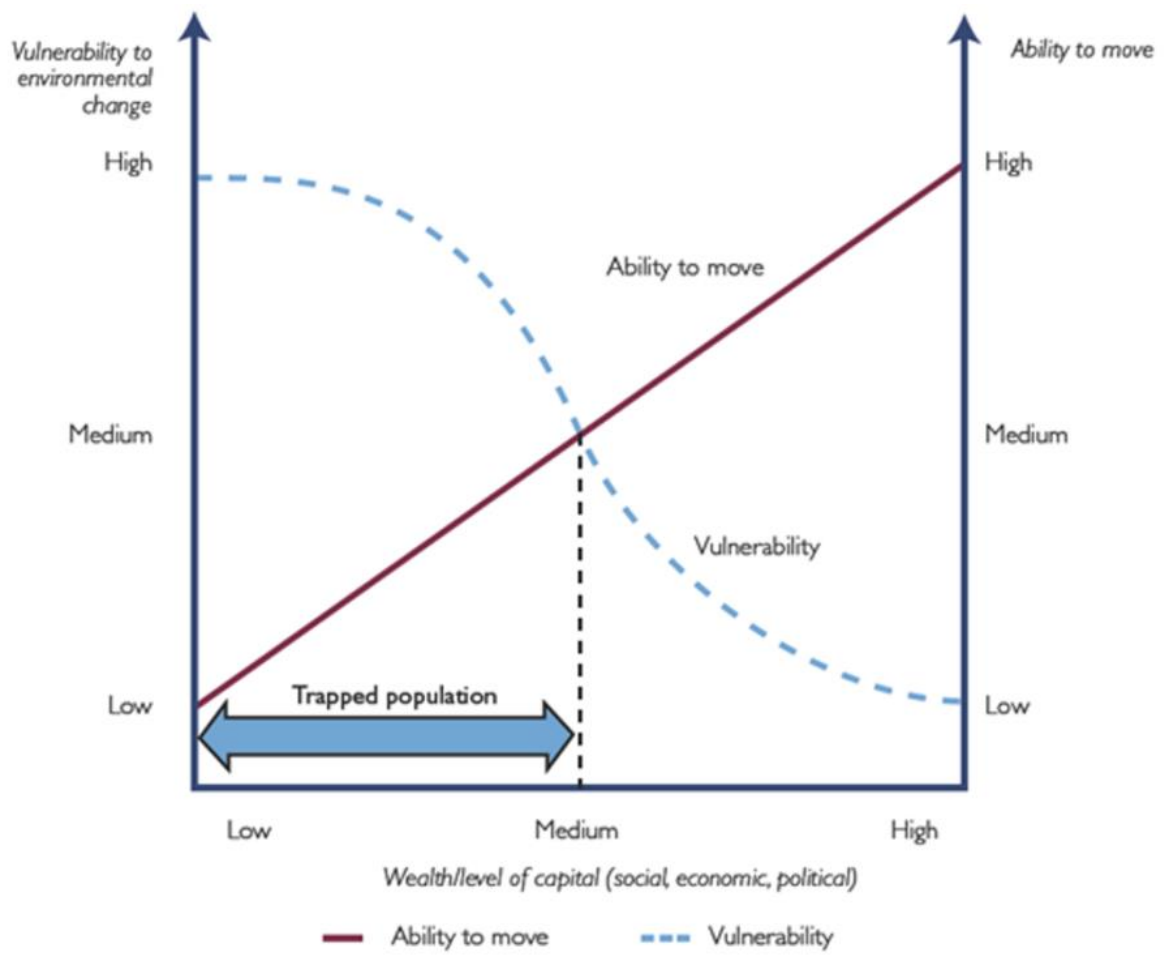

Fig. 1 The framework presented in the Foresight report indicated high and low-risk scenarios for people to end up 'trapped'. This depended on a population's vulnerability to environmental change, ability to move, and wealth/level of economic, social and political capital (Foresight 2011:14).

The framework referred to social and political capitals (such as a place to go, means to go, and potential fear for what is awaiting or left behind), however, the language conceptualising Trapped Populations was strongly economic. This raised concerns of neoliberal forces 
disguising financial and political benefits (Felli and Castree 2012; Baldwin 2016; AyebKarlsson et al. 2018). Repetitive use of words such as 'capital', 'wealth', 'resources', 'economic', 'poor' and 'low-income" surrounded the concept. This conceptual understanding potentially resulted in policy consequences through the perceptions and values reproduced in the language by policy-makers. These discursive ideas, inherited in the strongly financial framing, were surely not the intent by well-meaning 'trapped 'scholars. However, such conceptual development and linguistic reproduction ended up writing off immobility as a fairly simple and linear process.

The conceptual creation of Trapped Populations was followed by elaborations around who and how populations may end up 'trapped'. People's underlying vulnerabilities, exposure to hazards and recovery capacity were put forward as one way to outline the links between potential (im)mobility scenarios (Black et al. 2011, 2013). Immobility, displacement and migration were drawn out as complex and multidirectional connections. People could end up 'trapped 'during exposure to a hazardous event, but not after or during the recovery phase (Fig. 2). 
Fig. 2 Illustrates hazard impact, recovery and immobility connections

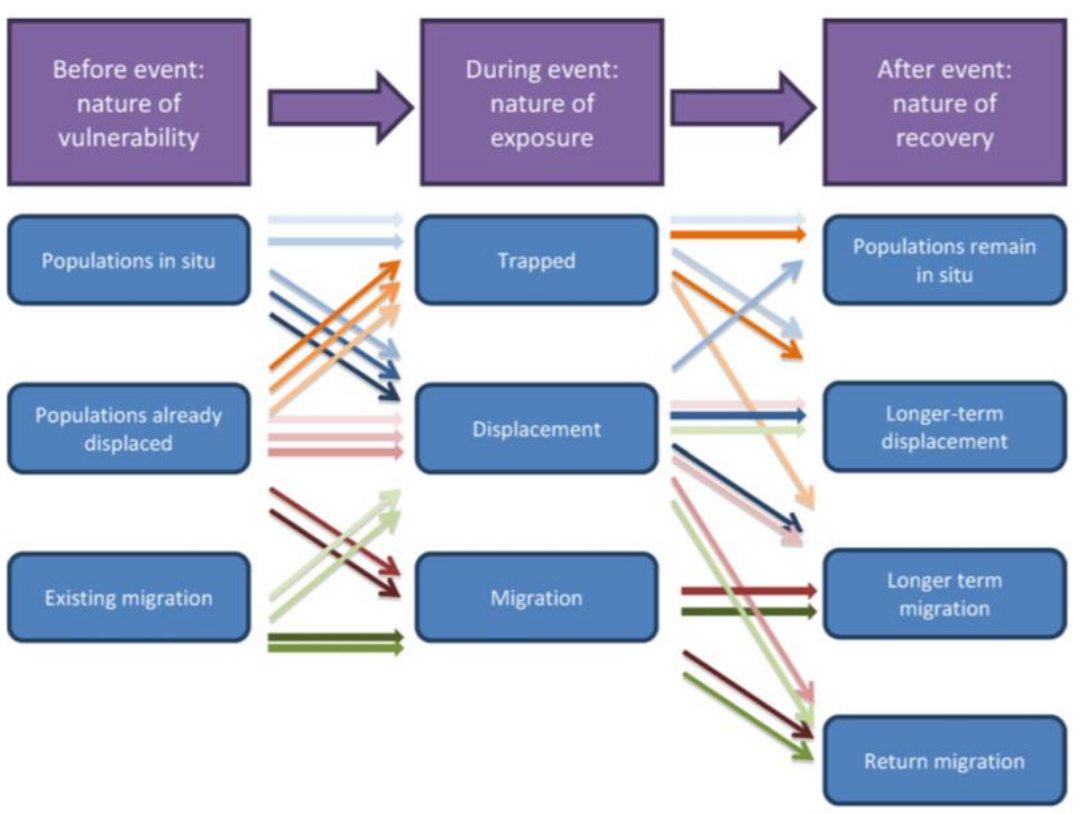

Fig. 2 The figure illustrated the multidirectional relationship between migration, displacement and immobility, and its link to vulnerability, hazard impact and recovery (Black et al. 2013: S38).

(Im)mobility is often categorised according to time, place, and choice. Time distinguishes between temporary (below three months), short-term (above three months) and long-term (above a year) mobility. Place differences between short- and long-distance or internal- and international moves. Choice refers to involuntary (or forced) and voluntary movements (Piguet 2013; Black et al. 2013). To be able to elaborate around choice, place and time of gendered disaster immobility in Bangladesh, we must first better understand the country context. The national government and the Red Crescent Society first established the Cyclone Preparedness Programme (CPP) after the deadly 1970 Bhola cyclone. CPP has helped reduce the loss of lives in the more recent cyclone strikes through their volunteers and Early Warning System (EWS). The CPP volunteers warn people of approaching cyclones and facilitate their evacuation to the shelters. Between the years of 1991 and 2007 the enlisted CPP volunteers more than doubled 
from 20,000 to over 42,000 (Haque 1995; Penning-Rowsell et al. 2013). The reduced cyclone fatalities were believed to be a result of these CPP efforts. The success included 350,000 people evacuating to 508 cyclone shelters during the 1991 cyclone Gorky. Nevertheless, a large number of people did not evacuate during cyclone Gorky, nor during cyclone Sidr in 2007 (Fig. 3). The estimated average evacuation in 2007 was not at all very different from the 1991 evacuation rate (Paul 2010; Chowdhury et al. 1993; Parvin et al. 2008).

Fig. 31991 and 2007 cyclone evacuation rates

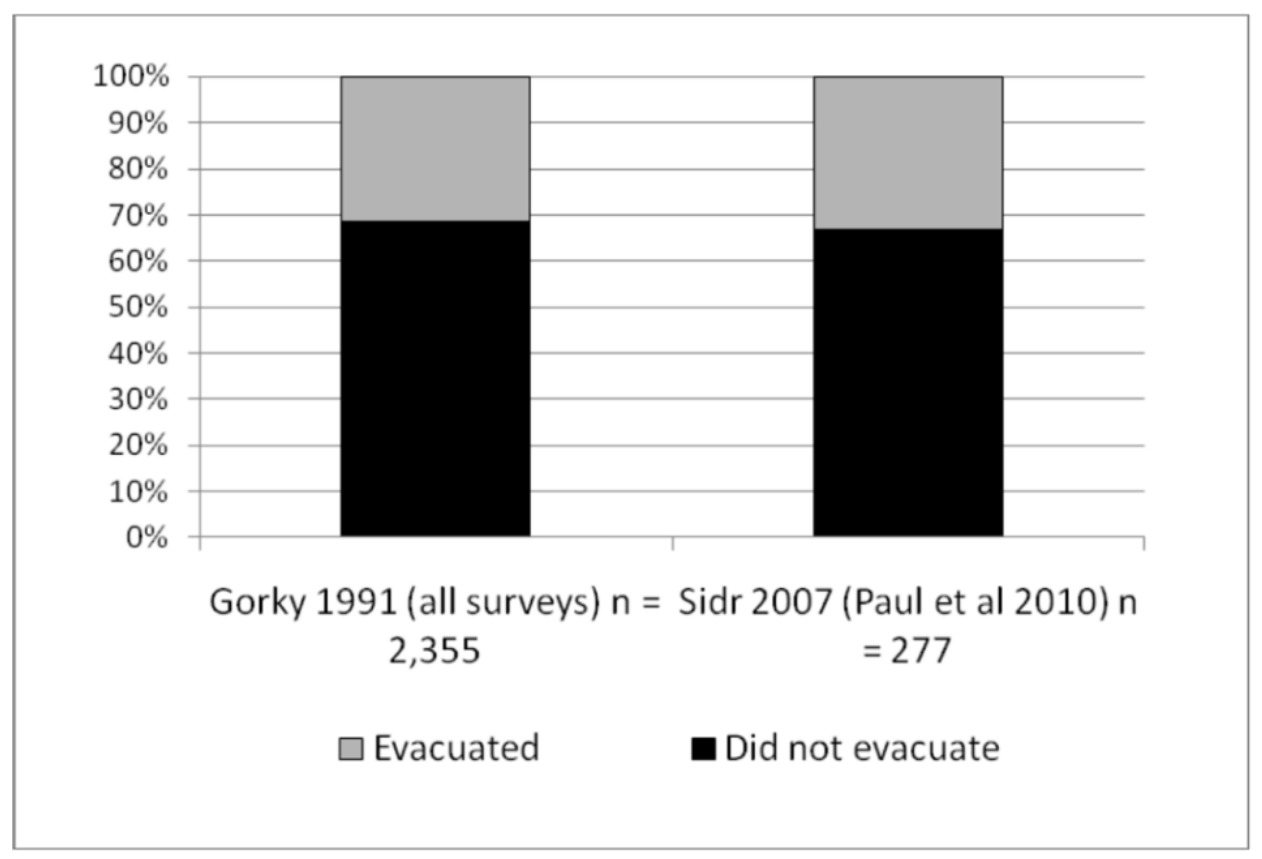

Fig.3 The figure raised concerns around non-evacuation behaviour during the 1991 and 2007 cyclone strikes. According to the household survey only a third of the respondents evacuated (Paul et al. 2010: Penning-Rowsell et al. 2013: S49).

The national government's evacuation estimations of Bangladesh's entire coastal residential area also aligned with these non-evacuation trends (Paul et al. 2011; Paul 2014). Out of the few people who evacuated, only a fragment chose to go to the cyclone shelters (Fig. 4). This 
was explained by diverse reasons including shelter availability, location and socio-normative constraints (Penning-Rowsell et al. 2013; Mallick 2014; Ahsan et al. 2016).

Fig. 41991 and 2007 evacuation locations

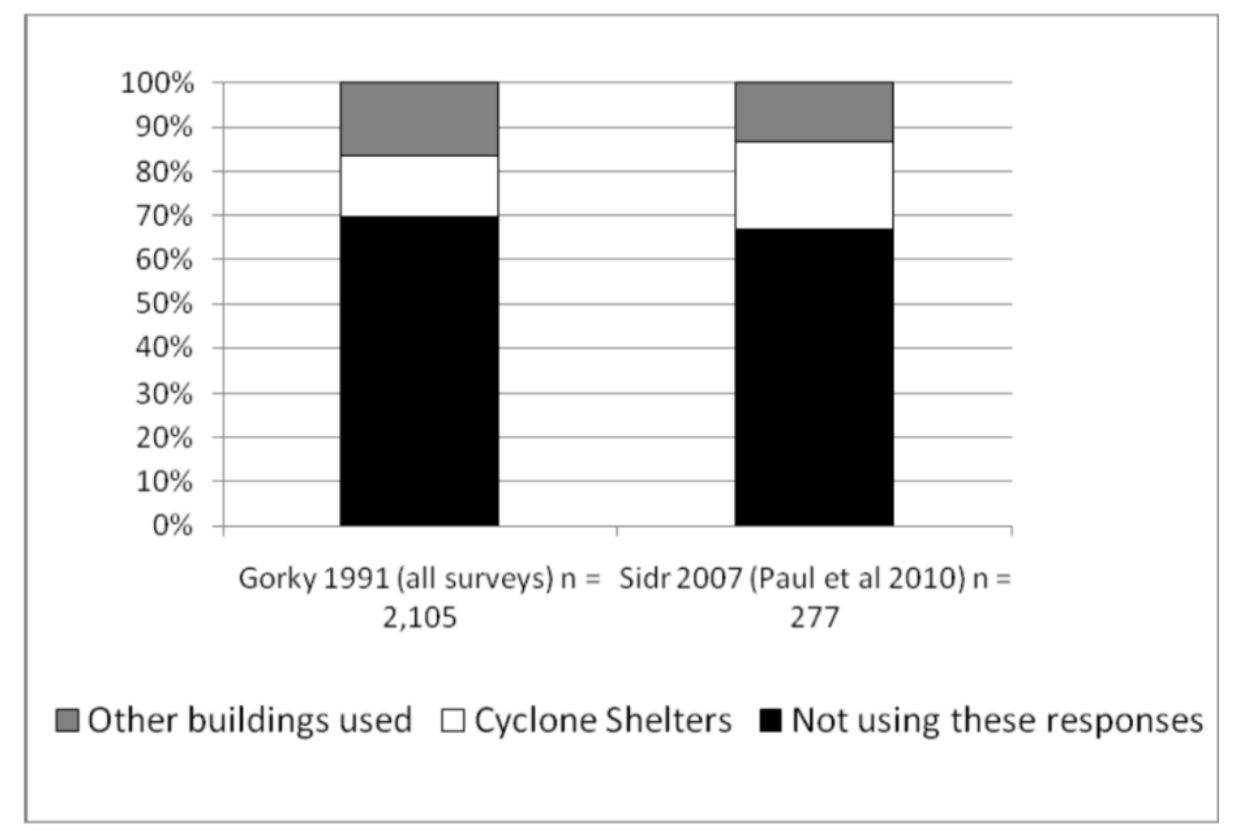

Fig. 4 Non-evacuation behaviour was not the only concern but as illustrated few out of the people who evacuated went to the cyclone shelters (Paul et al. 2010: Penning-Rowsell et al. 2013: S50).

The presented cyclone studies were also part of the 2011 Foresight initiative investigating future scenarios of (im)mobility in a climate changed world. A more comprehensive understanding of people's (im)mobility decision-making during disasters was therefore encouraged. The results challenged the idea that people with access to functional EWS and shelters simply would try to escape or move away from the hazard (Paul et al. 2010: PenningRowsell et al. 2013; Ayeb-Karlsson et al. 2019a). Ahsan et al. (2016) similarly found that 97 percent of 420 households in Khulna had received warning messages notifying them about 2009 cyclone Aila, and yet, only one in four (26 percent) evacuated. Everything from socio- 
economic background, livelihood mobility, to evacuation tools, influenced people's evacuation decisions (Asgary and Halim 2011; Paul 2012; Ahsan et al. 2016). Roy et al. (2015) however, argued that lacking or delayed warning messages determined whether or not people went to the shelters. A critical analysis of the values and perceptions around gendered disaster (im)mobility can support the understanding of who evacuates and why others do not. The storytelling methodology combined with a Discourse Analysis (DA) that were used in this study, proved to be an effective way of gathering such local insights and values.

\section{Theoretical framework}

The disaster vulnerability literature has been framed by behaviouralist and structuralist (or political ecological) scholars. The behavioralist perspective portrayed environmental and disaster vulnerability as a lack of planning and preparedness, while the structuralist viewpoint rather argued the vulnerability is deeply rooted in social structures (White et al. 2001; Cutter 2003; Adger 2006). The structuralist framing is strongly linked to the distribution of wealth and power (Blaikie et al. 1994; Oliver-Smith 1996). Meanwhile, from a behavioralist point of view, human mobility is a learnt social behaviour established through the interactions with the environment, or an' objective 'stimulus-response behaviour (e.g. Pavlov 1897; Watson 1913, 1930). From a behavioralist perspective, people have come to realise that moving away from environmental changes is the safest and most effective response. The structuralist point of view instead argues that human mobility, including the socio-psychological culture around the mobility behaviour, must be understood as part of a larger system. It is first when we uncover this structure or system, that we fully can understand what people think, perceive, feel, and ultimately, do (e.g. Lévi-Strauss 1955; De Saussure 2011). It was out of this idea, that a critical literature body known as post-structuralism was born (including scholars such as Michel Foucault and Judith Butler). This critical response rejected the idea of a self-sufficient system 
with static binary opposites ${ }^{3}$. The assumption that one word, out of the two in a pair, dominated the other was also rejected. According to the post-structuralists, the only way to fully understand the purpose of the binary opposites was to critically and separately analyse the term(s), and their relationship with their binary pairs. This was because knowledge, and the production of knowledge, was central to better understanding the structure. In other words, to understand an object (such as text, action or behaviour), it is necessary to study the system of knowledge that has produced the object, not only the object itself (Ayeb-Karlsson et al. 2018, 2019b, 2020; Ayeb-Karlsson 2020c).

This is also the way that this study applies the notion of Trapped Populations or immobility. The theoretical foundation guiding the analysis includes key concepts such as discourse, power, knowledge, binary opposites and gender. Many of these terms, have been developed and shaped by Foucauldian literature. Discourse, power and knowledge are not Foucauldian concepts, however, Foucauldian inspired scholars often supported and shaped their framing (Ayeb-Karlsson et al. 2018, 2019b, 2020; Ayeb-Karlsson 2020c). The Foucauldian inspired conceptualisation around (1) discourses ${ }^{4}$ expanded beyond 'language 'to include practices and behaviour (this differentiated from the framing of the 1950s structural linguistics), (2) power relations were enabled within a flexible and temporary network of people (unlike the Marxist top-down idea where power is obtained by the state), and (3)

\footnotetext{
${ }^{3}$ The term 'binary opposites' refers to a situation where a pair (words, things or characteristics such as manwoman, body-soul, black-white, east-west, and rural-urban) are defined against one and another. The system was seen as a fundamental organiser of all languages and thoughts.

${ }^{4}$ The concept of discourse is here defined as "the general domain of all statements, sometimes as an individualised group of statements, and sometimes as a regulated practice that account for a number of statements (Foucault 1972:80)."
} 
knowledge was conceptualised as a construction (rather than history of ideas) of a truth (Foucault 1972, 1977, 1981, 1982, 2002).

In the context of disaster immobility (or non-evacuation behaviour) in Bangladesh, some people will immediately consider evacuating to the cyclone shelters upon receiving a warning message while others will not. An unmarried woman may not find a public shelter as safe as an unmarried man, or a married woman. This could lead to the decision of staying behind. For some people, a public shelter may feel like an inappropriate social space, and evacuating, an inappropriate social behaviour. In this way, the social-norms and power relations in place can prevent people from evacuating. This is merely one example of how power and knowledge can influence the human decision-making process, immobilise, or trap people in a geographical place or social space (see Fig. 5). 
Fig. 5 Discursive decision-making model

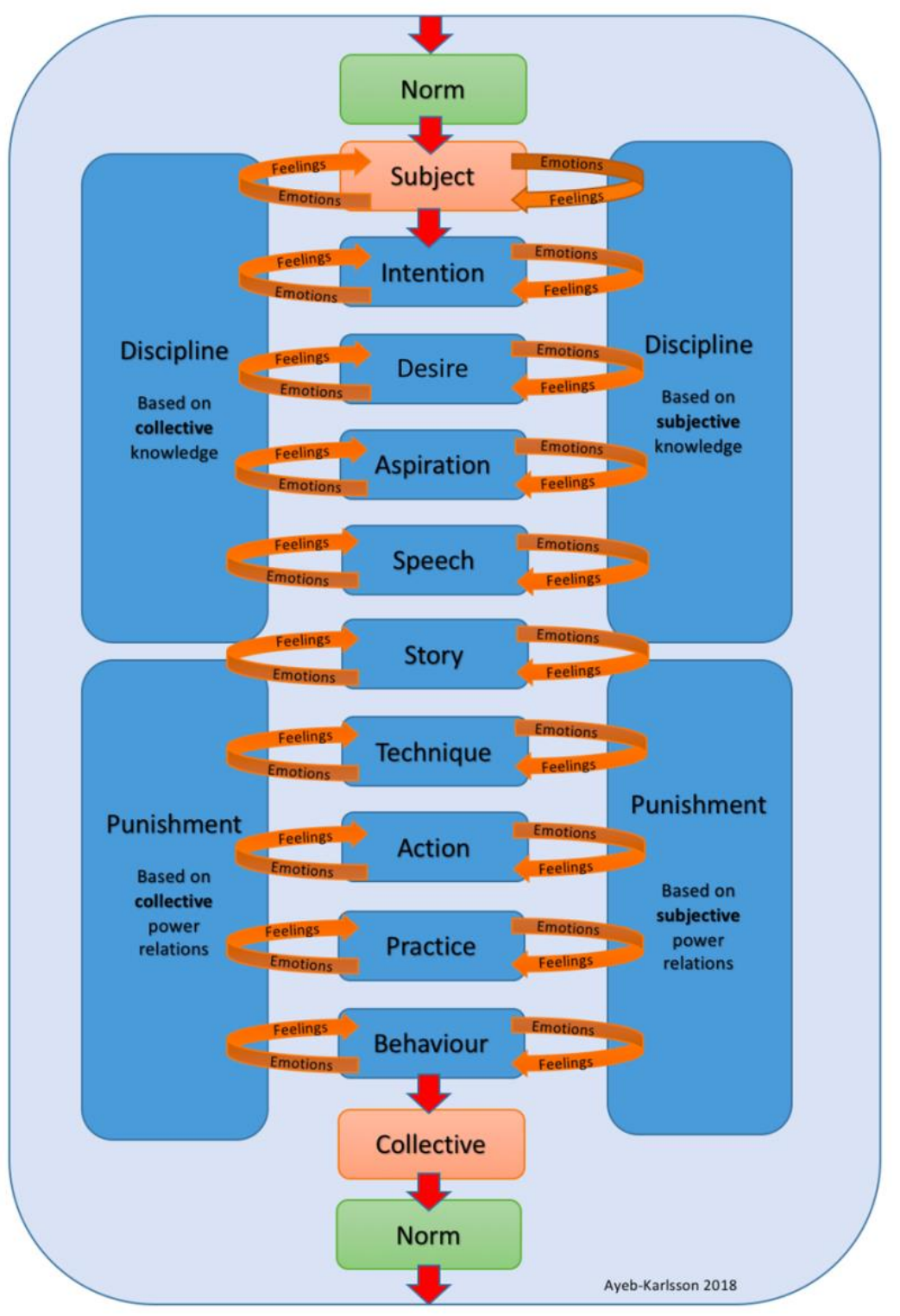

Fig. 5 The Foucauldian inspired figure presented the conceptual idea of how (im)mobility decision-making links to social-norms through the interaction of power (through punishment), and knowledge (through discipline) (Ayeb-Karlsson 2020c: 7).

Structural social processes often align with patriarchal power systems that reinforce gender imbalances (Anbarci et al. 2005; Neumayer and Plümper 2007; Rhodes et al. 2010). Gendered immobility (geographical, social, and psychological) and the vulnerability it may result in must therefore be understood through a range of socio-psychological systems. These 
include but are not limited to patriarchal hierarchies, religious and traditional practices, shame and honour, as well as gendered division of labour (Rashid and Michaud 2000; Stephens et al. 2013). This study will similarly extend upon the idea that social constructs of knowledge and power can constrain, as well as enable, people's decision-making or (im)mobility process (Foucault 1977, 1982, 1995; Butler 1997; Ayeb-Karlsson et al. 2019b, 2020; Ayeb-Karlsson 2020b, 2020c). The Foucauldian inspired conceptualisation of discursive (im)mobility decision-making will support the textual analysis and the storytelling data. This conceptual lens will help us understand in what ways gender influenced who evacuated during the cyclone strikes, why and how it impacted others to stay back.

\section{Method and study sites}

A discursive analytical approach is useful to explain social values such as binary structures between, for example, male and female characteristics (Foucault 1972, 1981, 1991; Fairclough 2003, 2010). Various scholars have elaborated around the order of discourses (see Foucault 2002). This structural social system is maintained through the separation of binary opposites; including the thought that masculine and feminine features ought to be kept apart (e.g. Hirdman 1990; Cornwall 2003; Kulick 2008).

In this Discourse Analysis (DA), local narratives were captured through the research conduction involving qualitative storytelling sessions in three coastal cyclone affected study sites of Bangladesh (Dalbanga South, Mazer Char and Gabtola). The storytelling sessions included personal in-depth life histories, key experience interviews and resettlement choice sessions, as well as collective focus group discussions involving story and narrative development. In total, 30 individuals contributed to about 90 interviewing sessions, and roughly 250 participants joined 15 group sessions. The gender balance of the informants was approximately 50/50. The group sessions were carried out as separate female or male sessions in a safe and private environment. This often made both men, and particularly women, feel 
more comfortable discussing gender roles. Adding to this, the final sample overall reflected the representation of livelihoods, migration history and socio-economic status in the study sites.

Respondent driven, or snowball sampling technique, where participating respondents support the identification of additional informants, facilitated the informant selection (Goodman 1961; Goel and Salganik 2010; Heckathorn 2014). The risk of a biased final sample was decreased by the fact that all three study sites were fairly small and isolated leading to most people knowing one another. The initial set of informants were also sampled from a diverse socio-economic backgrounds and geographic locations in the study sites (Brace-Govan 2004; Kurant et al. 2011). Narrative or storytelling methodology is a non-structured and participant-led open interviewing approach that allows space for the informants to construct storylines without unnecessary interruptions or questions. The methodology effectively captures valuable local perceptions, insights in socio-cultural values, normative boundaries and (dis)encouraged social behaviour. These social values and perceptions are often registered in the wider context around the storylines or in between the lines (Bell 2010; Ayeb-Karlsson et al. 2016; Conway et al. 2019; Ayeb-Karlsson 2020b). The methodology in this way provides a small window into people's discursive and subjective reasoning (Tschakert et al. 2019; AyebKarlsson et al. 2019a, 2019b; Tebboth et al. 2019; Ayeb-Karlsson 2020c).

\section{Using storytelling to understand gendered disaster (im)mobility ${ }^{5}$}

Three thematic areas of gendered binary opposites were detected in the storytelling data around perceptions of disaster (im)mobility. This analytical section is structured around these areas while supported by storytelling text extracts for transparency.

\footnotetext{
${ }^{5}$ This article uses the following referencing system (method, study site/informant gender/age, data conduction year), or to give an example, (LHI DLF60 2014) refers to Livelihood History Interview (LHI), Dalbanga South (DL), Female informant (F), 60 years old at the time of data collection taking place in 2014.
} 


\subsection{Spaces and places of male and female (un)safety}

Clear distinctions were outlined between female and male places of safety as well as potential dangers for women and men. Before elaborating around the binary opposites of 'safe and unsafe 'spaces, a few things need to be clarified. First of all, the Bengali word for 'evacuation ${ }^{6}$ ' translates into 'going to a safe place', but that does not necessarily refer to a cyclone shelter. Secondly, even though all three study sites had shelters located within the village areas, other places were sometimes referred to as 'safe places'. These included other strong buildings, such as schools and mosques, as well as elevated land, mounds and trees. Evacuation was therefore understood as moving to a safe place outside of the house:

\section{Extract 1}

His family decides whether or not to go to a safe place; elevated land or a cyclone shelter. If their residence is resilient to cyclones, then they must stay back and invite their neighbours in. /.../ When his family decided to go to the cyclone shelter, an unexpected flood pulled their son away. After the cyclone, his family and the villagers started looking for the boy. After a while, they found him dead (CSS DLM 2016).

\section{Extract 2}

He could not go to the shelter as it is located very far from his house. He saved his life with the help of a tree. After the flood wave started to go down, he climbed down and went to the shelter (CSS MCM 2016).

\section{Extract 3}

The wind was incredibly strong. The trees started to break and fell on top of the houses. The children started to scream. After that, the water came flowing into the house. When the water entered, my soul

\footnotetext{
${ }^{6}$ The Bengali expression generally used by people in the study sites when referring to cyclone evacuation is "nirapod jaygai jaoa" which in direct translation means 'going to a safe place'.
} 
ran away from me. It does not matter that there is a heavy storm and it breaks my house. We can take shelter under a tree if we need to, but the water? What can we do? Where are we supposed to go? We could try to swim, but I am not that strong (LHI DLF60 2014).

Terms such as 'distance' and 'location' in relation to the cyclone shelters were important to estimate potential risks. If the shelter was located far away from the house, or close to the river, it was sometimes described as safer to stay at home or move to a 'safe place 'close to the house, but far from the water.

These dangers applied to men as well as women, and were narrated by female as well as male informants:

\section{Extract 4}

Many families live far away from the cyclone shelter. They cannot come here during the cyclones so there is a need for more shelters (CSS GBM 2016).

\section{Extract 5}

I think I am more vulnerable because my house is located along the embankment's first line of houses. If I could manage to get some money, I would try to find a safe place. I would go there and buy some land. /.../ I would work so hard to pay that money back - every single cent. I just want to be able to put my family in safety, in a place where I do not have to worry about them dying in a cyclone strike or due to a flood (LHI GBM38 2014).

\section{Extract 6}

I do not go to the cyclone shelter. There is no point going as the shelter is located so close to the river. It is better to climb up and hold onto a banana tree than trying to get to the shelter. It is located next to the river. I live slightly away from the river, so if I go towards it, to save myself, I may end up dying anyway as I will be walking towards the river. It is better to stay at home. /.../ During cyclone Mahasen, people got really scared. They did not feel safe in the cyclone shelter. The shelter was shaking and the water from the river got so high with the storm that it seemed foggy outside. It is better to stay at home than to go to the shelter. /.../ The condition of the shelter is not good enough to withstand the strong winds of the storm. It was shaking so people thought the shelter was about to collapse. If it had collapsed, then we 
would all have died. /... The cyclone shelter is not built very well. The basement and the floors are quite ok, but the walls are not good enough. /.../ Those who live close to the riverbank may go to the shelter, but we are far from the river so we generally do not go. I went there once and I learnt my lesson. In my opinion, it is better to stay close to the banana trees than to go to the shelter. /.../ There are just three small rooms in the shelter that hardly fit one hundred families. How is it supposed to fit all of us? /.../ Those who arrive first will get a place, the rest of the people will have to try to sit on the balcony or take shelter on the rooftop. /.../ When we rush to the shelter during a cyclone strike we often hurt ourselves. The road to the shelter can be dangerous and it takes a long time to get there. Once a man was bringing his wife to the shelter and a tree fell upon her. The couple managed to reach the shelter, but the wife died after two years of suffering from the injuries. I also believe that the Angel of Blessing rather lives in the house (KES DLF61 2016).

The infrastructural state of the cyclone shelter was described as a gender-neutral danger or risk that could impact men as well as women equally. Several informants described how the shelter was unsafe. It was safer to stay at home as the shelter could break, fall down on top of people in the storm, or the flood waves could drown people that were trapped inside.

A few storytelling sessions linked shelter access to wealth and poverty. The narratives described how the village was poor and that some rich people within the villages received special treatment. The storylines proposed that the village was so poor that it could not even afford to repair the cyclone shelter, nor to build a new shelter, although, if there one day was to be a new shelter, it would surely end up in front of the rich houses:

\section{Extract 7}

We are so poor that we are not of much importance. Our cyclone shelter is even broken. If for example, at some point in the future, there would be a possibility of building a new cyclone shelter, then it will be built in front of houses looking like yours. I mean, in front of rich people's houses. /.../ The cyclone shelter here is damaged. All of the good shelters, or two to three-storey buildings, are located on the other side of the river (CSS MCM 2016). 
Women's vulnerability was described as increasing as they stepped outside the house to evacuate to the shelter. The described binary opposites separated women from men through both their clothing (and its limitations/restrictions) and their personality traits. Two male respondents compared and aligned women with children. Women were narrated as 'weak and afraid'. Similar to children, women did not know how to swim, while men were 'brave and experienced'as they worked outside the house. Fishermen even courageously stared the storm right in the eye, out on the open sea:

\section{Extract 8}

Women and children are mentally weak. They get afraid easily. Children cannot swim so sometimes mothers hold onto their children, and that may cause the death of them both. Men are brave and have often faced the storm out on the sea, while women have not lived through experiences outside of the house (KEI MCM30 2016).

\section{Extract 9}

Nevertheless, women here wear sarees most of the time. The sarees are usually 10-12 feet long so they cannot swim wearing this long piece of cloth. Men on the other hand, might be wearing a simple piece of clothes, such as a lungi. They can pull their lungi up if needed and thereby swim, or stay in the water longer. They can even take shelter in the trees (KEI MCM30 2016).

\section{Extract 10}

Women die because of their hair and clothing. They are also emotionally weak. Children are always fond of their mothers. Women cannot leave them during such an event. That is why they too become victims of the disaster (KEI GBM60 2016).

The outlined binary opposites revealed separate safe spaces for unmarried and married women. These storylines mainly described the cyclone shelters being unsafe. Unmarried women were portrayed as more vulnerable than women in general. The main risk referred to them being in danger of losing their honour. Dishonour could eliminate future marriage proposals and they would then become an economic burden to their families. Statements arguing that unmarried 
women should not evacuate were expressed by both female and male informants. Unmarried women did not belong in the cyclone shelters: "It just does not feel right", explained a male respondent:

\section{Extract 11}

It is not right [for unmarried women to go to the shelter] because it could create problems. /.../ I do not like women going to the shelter. It just does not feel right. Wherever they go, things happen (LHI GBM38 2016).

The storylines explained further what was meant by 'dishonour 'and 'lack of privacy'. Younger boys could sexually harass unmarried women and girls in the shelter(s). The men in the village were therefore responsible for ensuring that thugs with bad intentions were not let into the shelter(s), explained another male respondent:

\section{Extract 12}

There are some local thugs who have been told that they are not allowed to go inside [the shelter] because of the women. They are only allowed to stay on the balcony, roof, or some other isolated place. They are permitted inside. The regular mass of people generally have bad intentions, even during the time of a cyclone strike. /.../We therefore decide when they get to the shelter during the cyclone, whether they are allowed to enter or not (KES MCM24 2016).

In a female Collective Storytelling Session (see text extract 13), the tragic story of a young educated girl with big hopes and dreams for the future was told. The girl is sexually assaulted in the shelter and therefore cannot bear to live. She survives the cyclone only to take her own life due to the fear of losing her honour. The story communicates an alarming tale for caution; women are not safe in the shelters, nor are they able to ensure their own safety. Even when women are well aware of the risks, such as the girl in the story, they may still be subject to harm. The girl in the story evacuated to the shelter with her parents to ensure that she was safe. She also found a safe place in the shelter upon arriving. A safe place where no boys or men 
should be able to hurt her. She even warned other women of the potential dangers of being 'harmed 'by the men, and yet she ends up getting hurt. Staying behind is the only safe way forward. The home is the only safe place, the safest bet. Privacy can only be achieved in a space that does not allow outsiders:

\section{Extract 13}

The girl is educated, even though the villagers are not. She knows how the early warning system works and how to prepare for the cyclone strike. She informs the villagers of what they need to do, that they need to go to the cyclone shelter, and of all the necessary steps before going there. She helps the children, the elderly, and the pregnant to the shelter. She also advises them to bring their valuables. In the end, those who are strong go to the shelter. The girl tells them to bring dry food, so that they have something to eat later on, and matches to light a fire and stay warm. /.../ When the girl gets to the shelter, she tries to find a safe place where no boy can harm her. As she is educated, she has told everyone to please make sure that they are safe. 'If you feel that you are safe in a place, then do not move, or try to go somewhere else 'she says. This is also what she tells her parents. /.../ Anything can happen in the cyclone shelter, boys and men can try to harm her by grabbing hold of her hands, and by covering her mouth [so that she cannot scream for help]. The boys and men are from different places, they try to disturb her although she brought her parents with her for her protection. She already knows that women need to be careful of this. /.../ The girl decides not tell anyone what happened as she is afraid of losing her honour. She thinks to herself; I was an educated girl who was planning to create a better life for myself, but now, because of this, all is ruined. She decides that she does not want to live anymore, and kills herself by drinking poison (CSS DLF 2016).

Storylines involving dishonour went beyond those of unmarried women getting raped in the shelter. The narratives also captured descriptions of women getting hurt on their way to the shelters. 'Bad luck' entered the stories in reference to the death of young wives and their husbands. The bad luck got passed onto their children, that women were forced to abandon in order to re-marry. These abandoned children were portrayed as ending up choosing the wrong path in life and doing bad things for a living. Another female Collective Storytelling Session 
(see text extract 15) describes how people find the dead bodies of a baby and her mother after a cyclone strike. The woman was pregnant while evacuating and is thought to have given birth during the storm. The story indicates that not 'even 'pregnant women will be spared by the disaster:

\section{Extract 14}

In most cases, underaged young wives who lose their husbands during the cyclone strikes re-marry. The women leave their children behind in order to re-marry. These children often grow up choosing the wrong path in life, and start doing bad things for a living (CSS MCF 2016).

\section{Extract 15}

Even pregnant women got washed away by the flood. One woman gave birth to a baby all by herself after getting caught by the flood. She was found half naked and dead after three days. People also found her newborn baby next to her, unfortunately, the baby died too (CSS GBF 2016).

\subsection{Male educational knowledge and female faith in destiny}

Knowledge and education were important thematic areas in the storylines. To give an example, the girl who was sexually assaulted in the shelter was educated and knowledgeable (see text extract 13). She therefore informed others about the potential risks in the shelter and how to stay safe. The stories aligned education with knowledge, while villagers often lacked the ability to understand, prepare and avoid disasters risks:

\section{Extract 16}

Those who are educated have knowledge on different issues. We do not have this. We have no educational institutions other than the primary school. In your area, you will have the institutions so that you can educate yourself and come to know different things (CSS MCF 2016).

\section{Extract 17}

We get the warning messages, but most of the time these signals are not very effective. We estimated it wrong that time [during Sidr], but unfortunately, the warning message was right (KEI GBM38 2016). 


\section{Extract 18}

A little before Sidr, there was a cyclone warning message, but nothing happened that time. People therefore did not think that anything would happen during Sidr either. Those who were educated and more aware went to the shelter early, but others did not. It was first when the water level started going up that everyone realised what was about to happen, but then it was already too late. Some people still tried to reach the cyclone shelter, and some of them made it there, but others got stuck in their houses with the water level rising. Some people climbed up trees in order to save their lives (KEI GBM50 2016).

\section{Extract 19}

If we only had left earlier, when the water level was lower. If we only had started preparing in time, or left the cows behind. If we only had known what could happen, she would be with us today. Now I plan in time for the possibility of a cyclone strike. I buy food for one to two weeks, and I leave the cows behind. Nobody wants to leave them behind, but I have learned my lesson (LHI MCM80 2014).

Knowledge was also aligned with the binary opposites of female and male characteristics. To give an example, male and female respondents characterised the husband in relation to the wife. He was portrayed as 'smarter', 'more intelligent', and as someone the wife ought to go to for advice. However, this knowledge came with responsibility. Male informants in particular stated that as a man knows better what to do, he should never leave his wife behind. Some women also argued that they first and foremost followed the disaster instructions of their husbands. If these disaster instructions were to differ from the orders of the disaster volunteers, a husband's word still carried more weight. The stories also captured some elaborations around the punishment of a wife who did not agree with her husband:

\section{Extract 20}

I told my wife to go to the cyclone shelter, but she would not reason with me./.../ Not even when the storm increased and things turned from bad to worse. Her main concern was still the cows. /.../As the water level was rising fast, we did not have much time /.../ my son filled a bag with money, 30.000taka or so, and attached it to his lungi [traditional male clothing]. We headed off towards the cyclone shelter, my wife, my two sons and I, but as we got outside, we realised that we would never be able to make it. 
It was too far and the water was flooding with an enormous force. $/ . . /$ At one point, the stream caught hold of the moneybag. My son let go of his mother's hand to try to save the money that was being pulled away in the water. When he let go of her hand, the force was too much for my younger son to handle by himself. He lost hold of the grip around her hand. The water was too deep, its force too strong. We caught up with each other around a big tree. 'Where is your mother?', I asked. 'I lost her', he responded. We found her body the next morning (LHI MCM80 2014).

Religion was another thematic area that received much attention in the storylines. One study site in particular, Gabtola, registered more religious narratives. Religion and God's will were put before educational knowledge and disaster preparedness. These religious attitudes encouraged different behaviours from women and men. The male informants generally described that Allah will save he who tries to save himself, while the female informants sometimes referred to evacuation as 'pointless'. The men claimed that not evacuating would be 'foolish', while some women explained that their destiny was pre-determined. Ultimately, women's survival therefore did not depend on staying or going:

\section{Extract 21}

Even the Devil's heart goes soft in these circumstances. In this situation, he goes from door to door to warn the villagers. He tells them to go to the shelter, and advises them to listen to his words. As he approaches each and every door, he realises that most of the people have already died. He is the only one left standing, and therefore ought to save his own life (CSS GBM 2016).

\section{Extract 22}

It is all left in Allah's hands, who will survive and who will die. For example, in this village a mother and a child who were running towards the shelter got hit and separated by the storm surge. Later on, the mother felt some hair touching her feet in the water only to realise that it was her child. She grabbed hold of a tree to survive. When the storm stopped, people found her sitting in the top of that tree with her child. People think that this is a miracle, that she and her child survived the cyclone. It all depends on Allah (CSS GBM 2016). 


\section{Extract 23}

It all depends on Allah, not simply the cyclone shelter. Even if I take shelter in an iron cage, if Allah's wish is for me to die, I will die. /.../ We depend on Allah [not early warning systems] (LHI GBM38 2016).

\section{Extract 24}

When the cyclone strikes, nobody cares about others. People think about themselves. Normally, girls face more problems during the cyclones because of how they dress. They may also get hurt, on their hands, legs, or other body parts. Sometimes, trees even fall on top of people and they die. I know of a mass grave. I have seen many dead bodies in my life due to the cyclones. The people buried there did not even get proper burial clothes. Everyone's lifetime has already been decided upon by God. Allah decides whether you will die or live (CSS DLF 2016).

\subsection{Female and male experiences of emotional fear and mental trauma}

The final identified thematic area in the storytelling sessions related to strong feelings and emotions, such as fear, panic and psychological trauma as immobilising factors. People expressed being terrified of (themselves and family members) getting injured or dying on the way to the shelters. Some described having witnessed others getting hurt or dying during previous cyclone strikes. The traumatic experiences from 2007 cyclone Sidr, that struck at night when people were sleeping and killed a large number of people in the study sites, still haunted many of the informants. A female Collective Storytelling Session (see text extract 25) described how deep the fear from Sidr had been burnt into people's minds. Rumours of another cyclone soon after triggered such panic that people rushed and tried to force their way into the shelter. Some children were accidentally stepped on and killed in the commotion.

The psychological trauma from previous cyclone strikes left people feeling so anxious and emotionally paralysed that some of them stopped evacuating. The fear of dying after, for example, having witnessed the death of family members, ended up trapping people mentally. A male respondent who described having lost his wife and all his four children in Sidr, 
explained that he still refrains from evacuating to the shelter. ${ }^{7}$ He also did not think that women should go to the shelters as it did not feel right to him:

\section{Extract 25}

People have died as they tried to get into the cyclone shelter. Some people even stepped on children in panic, quite a few children died in the commotion (CSS DLF 2016).

\section{Extract 26}

Sidr struck on a Thursday night. It had been raining all day. Not too much, and not too intense, but back and forward. Later in the evening, the rain and wind increased. The flood came in around 9pm. The water level started rising. It filled my whole house with water. I got stuck in my house with my wife and my children, while the house was going under water. We had water all the way up to our heads. Water pouring into our mouths. A person can stay under water for two minutes maximum, maybe less, but I was under water for at least three to four minutes. /.../ I could not see any of my family members. It was dark and wet. /.../ I somehow managed to break the roof of my house. I do not know where I got the strength from, but I remember my hand going through the roof and out of the house. /.../ I lost the grip around my son's hand. He got pulled away from me together with the rest of my family. /.../ After Sidr, I became anxious. I cannot seem to relax. Especially during [cloudy and rainy] days like these /.../. I feel the breeze coming in from the sea, and it forces me to remember. I cannot stand that breeze anymore. /.../ I had a wife, two sons, and two daughters. They were my family. All died in Sidr. Everyone except me. My current wife also had a husband, a son, and a daughter. They also died in Sidr. /.../ I am the only one who survived from my family. I survived, but my head and my mental wellbeing did not. I am not stable. When a person faces such a tremendous loss, he ends up frustrated. All my four children and my wife died, I am the only person left alive. How could I possibly be mentally stable? I have fallen apart (LHI GBM38 2014).

\section{Extract 27}

These hazards keep coming back every year. Besides the mental traumas that they leave behind, the worst impact upon people is the loss of human lives on an annual basis. Money and time can reduce

\footnotetext{
${ }^{7}$ Besides text extract 26, see also text extracts 11,17 and 22 , for further elaborations
} 
damages, but they cannot return a lost life. /.../ I have lost many things that were emotionally valuable to me. Some gifts from loved ones, and other important things. Things that were my whole world. You can provide me with a huge sum of money, but you can never return those things to me. They were priceless. At the same time, I witnessed many of my relatives dying while screaming and crying. I failed to help them, I failed to save their lives. This can never leave me completely happy. Nothing you would try to provide me with would ever be enough to fix that. /.../ Physical damage and the loss of resources that were emotionally important to us are unforgettable losses. /.../ Some internal losses may also take place. /.../ During the cyclones, some people get injured internally. Injured within such an important organ that he or she may face complications afterwards. They may approach doctors and seek medical treatment in secret, but some losses cannot be healed by doctors. /.../ People face mental issues because of these traumas. Family problems arise as a result, and they grow larger by each day. However, when we talk about floods, it is often the economy that receives the most importance. /.../ The only doctors that came to see us [after the cyclone] were [physical] medical specialists. They were not able to give mental or psychological support to the victims here. /.../ We noticed that some children would bury their toys after here and there. We also often heard them saying:' Stop the game! Otherwise, the cyclone will come'. /.../ From the children's behaviour we sensed their fear. They often repeated:' When will the flood strike again? Will I have to go [to the shelter] again then, or will I die next time? If it happens again, then please promise me not to leave me'. /.../ The parents reassured their children that the flood will not come back, and that they should go back to living life in the way they had done before the disaster stroke (KEI GBM60 2016).

Two men elaborating around the internal losses they experienced and witnessed clearly outlined empirical descriptions of non-economic losses and damages. It is interesting that both men referred to the loss of wellbeing as a severe disaster impact. Mental health must be incorporated into the very core of the conceptual development of Non-Economic Loss and Damage, as well as into its application within research and policy.

The two male informants delicately narrated the sociopsychological effects of such losses, while also indicating the lack of mental health support services. The storylines even separated (physical) doctors and (psychological) doctors. The term 'doctor' was used to 
describe health service providers tending to bodily damages as they are the only doctors available. This is also why the elderly man explained that these internal losses and damages (or mental injuries) cannot be healed by doctors. It is clear that robust mental health assessment and support are lacking, albeit required. People did not stand a chance to work through the traumas left behind in the path of the cyclone. The narratives also described longer-term sociopsychological impacts, such as domestic abuse and reduced developmental opportunities for children and adolescents.

The storylines around mental ill-health and psychological trauma must be aligned with gender roles and expectations of social identities. The fragility of a man experiencing posttraumatic stress, or mental and emotional 'weakness 'does not concur with the knowledgeable, brave and fearless fisherman facing cyclones out at sea. A male informant elaborated further around the lack of mental and psychological support services after the cyclone events. He described how these 'internal damages' were not healed, nor prioritised, and therefore resulted in longer-term family and social issues.

Meanwhile, the male respondent who lost his four children and wife in cyclone Sidr, remarkably explained that he did not think that women should evacuate to the shelter. Some may find that opinion surprising, but perhaps it is not surprising at all. From the revealed perceptions around the existing gender roles, his main responsibility during the cyclone strike is to ensure that he protects his family. He does not only bare the ultimate knowledge and decision-making power, but he also bares the heavy responsibility of getting his family to safety. From this point of view, the loss of this man's entire family must have felt unbearable and socially emasculating. He failed his ultimate duty and role in the household. 


\section{Discussion}

This study showcased that although financially and practically founded disaster immobility can be important, complex socio-psychological and political factors can be just as immobilising. People sometimes stayed behind as they could not afford to leave their belongings, livestock and houses behind. However, social norms and power relations, such as gender identity, as well as psychological trauma and feelings, were just as important immobilising factors. We must therefore combine financially, politically, socially and psychologically immobilising elements to be able to comprehend the entire network. The findings illustrated how these social gender values, and people's subjective understanding of the gender roles shaped the societal structure. The effects of these gendered power positions upon DRR were, for example, seen in the outlined distinctions between safe and unsafe spaces, or the gendered division of knowledge and decision-making power around disaster preparedness, planning and evacuation.

The storylines also captured gendered nuances in people's social values. For example, unmarried and married women did not inhabit the same vulnerability. A married woman was to be protected by her husband, while an unmarried woman was not fully safe until she was married. A married woman who failed to adhere the advice and guidance of her husband could also find herself facing a tragic end to her life. Men knew whether or not to evacuate as well as who in the household ought to go to the shelter. A woman must therefore accept any arguments aroud why she ought to stay behind. This is when God, and her destiny being predetermined, came into play. Meanwhile, women who did not evacuate when their husbands urged them to, or evacuated to the shelters without a male guardian may find themselves socially punished and even physically harmed or sexually assaulted. In this way, the storytelling data captured powerful and insightful immobilising gender attitudes. An important step forwards for climate policy and DRR policy will be to ensure that our current frameworks comprehensively include socio-psychological disaster immobility. Further studies in extended 
geographical and contextual settings will also be important to better inform how to effectively support our most vulnerable populations (Cutter 2017; Ayeb-Karlsson et al. 2019a; AyebKarlsson 2020a).

Gendered values feeding into mental ill-health and psychological trauma, such as PostTraumatic Stress Disorders and fragmented wellbeing, which in turn resulted in disaster immobility, was another key finding of this storytelling study. In this research area, climate change and health scholars (such as Watts et al. 2017, 2018, 2019) are urging for more empirical evidence from diverse research settings. We still have a long road ahead of us here. This study illustrates the importance of investigating gendered values around mental health, local understandings of wellbeing, and wellbeing loss in general. This is a relatively unexplored research topic that must be prioritised.

The empirical insights of this study delicately outlined how disaster related noneconomic losses and damages impacted people's (im)mobility and wellbeing. Mental wellbeing must be stronger tied into wider climate policy debates (such as the IPCC, UNFCCC, UNDRR and the SDGs). In the area of UNFCCC, the literature body on Non-Economic Losses and Damages represents an interesting research area (UNFCCC 2013, 2015; Tschakert et al. 2019). The two potentially powerful policy concepts, Non-Economic Loss and Damage and Trapped Populations, have until today experienced a lack of attention within academic and policy. Critical literature applying the concepts are still rather scarce but slowly increasing. The research area represents a key opportunity for health, social science and climate change interdisciplinary scholars to join the quest.

There are also clear evidence based recommendations to be drawn from this research. First of all, there is a need to better incorporate gender and emotional wellbeing into our DRR policies and responses. For example, female and male informants expressed in this study that women, and particularly unmarried women, were not safe in the cyclone shelters. Women 
described the risk of being sexually assaulted, on their way to, as well as in, the shelters. The narratives made the level of distress and psychological desperation clear by explaining that such an event may trigger suicide ideation or even completed fatal intentional self-harm.

The way forward must include an evaluation of the function, location and state of the cyclone shelters. To give an example, in this study schools and religious buildings were often described as being re-used as larger cyclone shelters. In a sense, people had functional cyclone shelters in place, but their locations often aligned with social centres, including marketplaces and harbours. Imagine instead that people had access to smaller and more widespread 'community' shelters. This could result in a higher number of people, and their family members, feeling emotionally more comfortable with the process of evacuation. It is likely that people would feel safer with the shorter evacuation distances, as well as with the close neighbours and local crowd seeking shelter there (Ayeb-Karlsson 2020a, 2020c).

Secondly, researchers and policy stakeholders must advocate for more critical peoplecentred investigations on gendered disaster (im)mobility. This study barely represents a beginning of the work to widen our understanding of the complex subjective and psychosocial processes surrounding gendered disaster immobility or 'trapped 'populations. The study is part of a new critical literature body investigating how psychosocial wellbeing relates to climateinduced immobility, but further research must follow.

A wider comprehension of why psychosocial processes can result in compromised wellbeing, and disaster immobility, will show how to best support vulnerable people. To achieve this, we need extended people-centred investigations in different geographical, cultural and social settings. This research will place us in a stronger position as we thereby can outline similarities and differences in the gendered disaster (im)mobility. A number of findings from this study are location specific, while others may be applied to a wider social context. To give 
an example, a deeper understanding of psychosocial processes and their relationship to subjective (im)mobility gives us insights into human behaviour and responses to hazards.

Compromised wellbeing was described as a psychological factor immobilising people, and often in combination with their psychosocial gender roles. For example, men expressed finding it extremely traumatic when failing to protect or save family members in a cyclone strike as this was their ultimate male responsibility. Meanwhile, women facing sexual abuse in the shelters felt a reduction in their female value with the loss of honour. As a result, these women sometimes saw no other escape but to end their lives. This brings us to the third and final recommendation, extensive mental health assessment and service provision must be part of the disaster response. In relation to this, there is a need to build onto what we already know of trauma, loss and grief. Traumatic events such as experiencing the loss of family members, belongings, and safety, or witnessing injuries and death of loved ones, may result in lifelong impacts on a person's wellbeing.

Effective and sustainable treatment plans to heal trauma, as well as financial resources for the provision of such services must be in place. This represents an urgent concern that DRR policy-makers, action and financial stakeholders must address. Political and financial efforts should be made to ensure that people who have faced hazards have immediate access to psychological support after the event. As observed in this study, leaving people with open psychological wounds, such as post-traumatic stress and acute anxiety, is seen to increase their vulnerability to cyclone strikes in the future. People in this study, for example, expressed feeling so paralysed by fear after having lost family members in previous cyclone strikes that they no longer evacuated, nor wanted their family members to attempt to seek shelter.

\section{Conclusion}

This study has identified various gendered notions around how and why people may end up immobile or 'trapped 'when a disaster strikes. People's perceptions and reasoning behind this 
gendered disaster immobility illustrate their inherent complex social and subjective components. Future research and policy within the area of Disaster Risk Reduction must therefore move beyond simple and linear vulnerability relations. It is important to acknowledge that immobilising notions are more than climatic or environmental. As observed in this study, the natural environment was not the only linear 'trapping 'factor. A more people-centred understanding of global environmental changes will be the only way to achieve a more sustainable future. A future where the only thing we know for certain is that the disasters will keep striking and impacting people's wellbeing. In a world where he does not like her going to the shelter when the disaster strikes, change is needed as we all have the right to be safe. 


\section{References}

Adger, W.N. (2006). Vulnerability. Global Environmental Change 16(3): 268-281. http://dx.doi.org/10.1016/j.gloenvcha.2006.02.006

Ahsan, M.N., Takeuchi, K., Vink, K. and Warner, J. (2016). Factors affecting the evacuation decisions of coastal households during Cyclone Aila in Bangladesh. Environmental Hazards 15(1): 16-42. https://doi.org/10.1080/17477891.2015.1114912

Alam, K. and Rahman, M.H. (2014). Women in natural disasters: A case study from southern coastal region of Bangladesh. International Journal of Disaster Risk Reduction 8: 68-82. doi: 10.1016/j.ijdrr.2014.01.003

Anbarci, N., Escaleras, M. and Register, C.A. (2005) Earthquake fatalities: the interaction of nature and political economy. Journal of Public Economics 89: 1907-1933. https://doi.org/10.1016/j.jpubeco.2004.08.002

Asgary, A. and Halim, A. (2011). Measuring people's preferences for cyclone vulnerability reduction measures in Bangladesh. Disaster Prevention and Management: An International Journal 20(2): 186-198. https://doi.org/10.1108/09653561111126111

Ayeb-Karlsson, S. (2018). When the disaster strikes: (Im)mobility decision-making in the context of environmental shocks and climate change impacts. Doctoral Thesis (DPhil). Brighton: University of Sussex. Accessed online [20.12.2018] http://sro.sussex.ac.uk/80447/1/Ayeb-Karlsson\%2C\%20Sonja.pdf

Ayeb-Karlsson, S. (2020a). When the disaster strikes: Gendered (im)mobility in Bangladesh. Climate Risk Management, 29, 100237.doi:https://doi.org/10.1016/j.crm.2020.100237 
Ayeb-Karlsson, S. (2020b). 'When we were children we had dreams, then we came to Dhaka to survive': urban stories connecting loss of wellbeing, displacement and (im)mobility Climate and Development. doi: https://doi.org/10.1080/17565529.2020.1777078

Ayeb-Karlsson, S. (2020c). No Power without Knowledge: A Discursive Subjectivities Approach to Investigate Climate-Induced (Im)mobility and Wellbeing. Social Sciences, 9(6), 103. doi:https://doi.org/10.3390/socsci9060103

Ayeb-Karlsson, S., van der Geest, K., Ahmed, I., Huq, S. and Warner, K. (2016). A people-centred perspective on climate change, environmental stress, and livelihood resilience in Bangladesh. Sustainability Science 11(4): 1-16. https://doi.org/10.1007/s11625-016-0379-z

Ayeb-Karlsson, S., Smith, C.D. and Kniveton, D. (2018). A discursive review of the textual use of 'trapped 'in environmental migration studies: The conceptual birth and troubled teenage years of trapped populations. Ambio 47(5): 557-573 doi: https://doi.org/10.1007/s13280-017-1007-6

Ayeb-Karlsson, S., Kniveton, D., Cannon, T., van der Geest, K., Ahmed, I., Derrington, E. M., . . Opondo, D. (2019a). I will not go, I cannot go: Cultural and social constraints to disaster preparedness in Asia, Africa and Oceania Disasters 43: 752-770. doi: https://doi.org/10.1111/disa.12404.

Ayeb-Karlsson, S., Fox, G., and Kniveton, D. (2019b). Embracing uncertainty: A discursive approach to understanding pathways for climate adaptation in Senegal. Regional Environmental Change 19: 1585-1596. doi:10.1007/s10113-019-01495-7.

Ayeb-Karlsson, S., Kniveton, D., \& Cannon, T. (2020). Trapped in the prison of the mind: Notions of climate-induced (im)mobility decision-making and wellbeing from an urban informal settlement in Bangladesh. Palgrave Communications 6(62): 1-15. doi:10.1057/s41599-020-0443-2 
Baldwin, A. (2016). Premediation and white affect: climate change and migration in critical perspective. Transactions of the Institute of British Geographers 41(1): 78-90. doi: $10.1111 / \operatorname{tran} .12106$

Bell, L.A. (2010). Storytelling for social justice: Connecting narrative and the arts in antiracist teaching. London and New York: Routledge. ISBN: 9781136975073

Bhatta, G.D., Aggarwal, P.K., Poudel, S., Belgrave, D.A. (2015) Climate-induced migration in South Asia: Migration decisions and the gender dimensions of adverse climatic events. Journal of Rural and Community Development 10(4). https://hdl.handle.net/10568/75788

Black, R. and Collyer, M. (2014). “Trapped” Populations: Limits on mobility at time of crisis. In Martin, S.F., Weerasinghe, S. and Taylor, A. (Eds.). Humanitarian Crises and Migration. Causes, Consequences and Response. (pp. 287- 305). London: Routledge. ISBN: 9780203797860

Black, R., Bennett, S.R.G., Thomas, S.M., Beddington, J.R. (2011) Climate change: Migration as adaptation. Nature 478(7370): 447-449. https://doi.org/10.1038/478477a

Black, R., Arnell, N.W., Adger, W.N., Thomas, D. and Geddes, A. (2013). Migration, immobility and displacement outcomes following extreme events. Environmental Science \& Policy 27: S32-S43. https://doi.org/10.1016/j.envsci.2012.09.001

Blaikie, P., Cannon, T., Davis, I. and Wisner, B. (1994). At risk: Natural hazards, people's vulnerability and disasters (First Ed.). London: Routledge. ISBN: 0415084768

Blondin, S. (2020). Understanding involuntary immobility in the Bartang Valley of Tajikistan through the prism of motility. Mobilities 1-16. doi:10.1080/17450101.2020.1746146 
Boyd, E., James, R.A., Jones, R.G., Young, H.R., Otto, F.E.L. (2017) A typology of loss and damage perspectives. Nature Climate Change 7, v.10. doi: nclimate3389

Brace-Govan, J. (2004). Issues in snowball sampling: The lawyer, the model and ethics. Qualitative Research Journal 4(1):52. ISSN: 14439883

Brown, K., Adger, W.N., Devine-Wright, P., Anderies, J.M., Barr, S., Bousquet, F., Butler, C., Evans, L., Marshall, N., Quinn, T. (2019) Empathy, place and identity interactions for sustainability. Global Environmental Change 56, 11-17. https://doi.org/10.1016/j.gloenvcha.2019.03.003

Butler, J. (1997). The psychic life of power: Theories in subjection. CA: Stanford University Press. ISBN: 0804728127

Cannon, T. and Müller-Mahn, D. (2010). Vulnerability, resilience and development discourses in context of climate change. Natural Hazards 55(3): 621-635. https://doi.org/10.1007/s11069-010-9499-4

Chowdhury, A.M.R., Bhuyia, A.U., Choudhury, A.Y. and Sen, R. (1993). The Bangladesh cyclone of 1991: Why so many people died. Disasters 17(4): 291-304. https://doi.org/10.1111/j.1467-7717.1993.tb00503.x

Conway, D., Nicholls, R. J., Brown, S., Tebboth, M.G.L., Adger, W.N., Ahmad, B., ... Wester, P. (2019). The need for bottom-up assessments of climate risks and adaptation in climate-sensitive regions. Nature Climate Change. doi:10.1038/s41558-019-0502-0

Cutter, S. L. (2017) The forgotten casualties redux: Women, children, and disaster risk. Global Environmental Change 42, 117-121. doi:https://doi.org/10.1016/j.gloenvcha.2016.12.010

Cutter, S.L. (2003). The vulnerability of science and the science of vulnerability. 
Annals of the Association of American Geographers 93(1): 1-12.

https://doi.org/10.1111/1467-8306.93101

Cutter, S. L. (1995) The forgotten casualties: women, children, and environmental change. Global Environmental Change 5(3), 181-194. doi:https://doi.org/10.1016/09593780(95)00046-Q

Cornwall, A. (2003). Whose voices? Whose choices? Reflections on gender and participatory development. World development 31(8): 1325-1342. https://doi.org/10.1016/S0305-750X(03)00086-X

Elliott, J.R. and Pais, J. (2006). Race, class, and Hurricane Katrina: Social differences in human responses to disaster. Social Science Research 35(2): 295-321. https://doi.org/10.1016/j.ssresearch.2006.02.003

Enarson, E. (1998). Through women's eyes: A gendered research agenda for disaster social science. Disasters 22(2): 157-173. https://doi.org/10.1111/1467-7717.00083

Fairclough, N. (2003). Analysing Discourse: Textual analysis for social research. London: Routledge. ISBN: 0415258936

Fairclough, N. (2010). Critical discourse analysis: The critical study of language. London: Routledge. ISBN: 1405858222.

Felli, R. and Castree, N. (2012). Neoliberalising adaptation to environmental change: Foresight or foreclosure? Environment and Planning A: International journal of urban and regional research 44(1): 1-4. doi:10.1068/a44680

Foresight (2011). Migration and global environmental change: Future challenges and opportunities. Final Project Report. London: The Government Office of Science.

Fothergill, A. (1996). Gender, risk, and disaster. International journal of mass emergencies and disasters 14(1): 33-56. ISSN: 02807270

Foucault, M. (1972). The archaeology of knowledge. New York: Irvington Pub. 


\section{$\underline{\text { ISBN: } 0394471180}$}

Foucault, M. (1977). Discipline \& Punish: The birth of the prison. Sheridan, A. (Trans.). London: Viking. ISBN: 0713910402

Foucault, M. (1981). The order of discourse. In Young, R.J.C. Untying the text: A post-structuralist reader. McLeod, I. (Trans.). London: Routledge. ISBN: $\underline{0710008058}$

Foucault, M. (1982). The subject and power. Critical inquiry 8(4): 777-795. https://doi.org/10.1086/448181

Foucault, M. (1991). Governmentality. In Burchell, G., Gordon, C. and Miller, P. (Eds.). The Foucault Effect: Studies in Governmentality with Two Lectures by and an Interview with Michel Foucault. Chicago: University of Chicago Press. ISBN: $\underline{9780226080451}$

Foucault, M. (1995). Discipline \& Punish: The birth of the Prison. New York: Vintage Books. ISBN: 0679752552

Foucault, M. (2002). The order of things: An archaeology of the human sciences. London and New York: Routledge. ASIN: B002JJQOPU

Goel, S., and Salganik, M. J. (2010). Assessing respondent-driven sampling. Proceedings of the National Academy of Sciences 107(15): 6743-6747. doi:10.1073/pnas.1000261107

Goodman L.A. (1961). Snowball sampling. Annals of Mathematical Statistics 32(1):148170. doi:10.1214/aoms/1177705148

Haque, C.E. (1995). Climatic hazards warning process in Bangladesh: Experience of, and lessons from, the 1991 April cyclone. Environmental Management 19(5): 719734. https://doi.org/10.1007/BF02471954

Heckathorn, D. D. (2014). Respondent-Driven Sampling: A New Approach to the Study of 
Hidden Populations*. Social problems 44(2): 174-199. doi:10.2307/3096941

Hirdman, Y. (1990). The gender system: Theoretical reflections on the social subordination of women. [Genussystemet-reflexioner kring kvinnors sociala underordning]. Tidskrift för genusvetenskap 3: 49.

Jordan, J.C. (2018) Deconstructing resilience: Why gender and power matter in responding to climate stress in Bangladesh. Climate and Development 1-13. https://doi.org/10.1080/17565529.2018.1442790

Kelman, I. (2019). Axioms and actions for preventing disasters. Progress in Disaster Science 2, 100008. doi:https://doi.org/10.1016/j.pdisas.2019.100008

Kulick, D. (2008). Gender Politics. Men and Masculinities 11(2): 186-192. doi: $\underline{10.1177 / 1097184 \times 08315098}$

Kurant M., Markopoulou A. and Thiran P. (2011). Towards unbiased BFS sampling. IEEE JSAC 29(9): 1799-1809. doi:10.1109/jsac.2011.111005

Lévi-Strauss, C. (1955). Tristes Tropiques. Paris: Plon. ISBN: 9780141197548

Logan, J.R., Issar, S., Xu, Z. (2016) Trapped in Place? Segmented Resilience to Hurricanes in the Gulf Coast, 1970-2005. Demography 53, 1511-1534. https://doi.org/10.1007/s13524-016-0496-4

Mallick, B. (2014). Cyclone shelters and their locational suitability: An empirical analysis from coastal Bangladesh. Disasters 38(3): 654-671. https://doi.org/10.1111/disa.12062

Mallick, B., and Vogt, J. (2012). Cyclone, coastal society and migration: empirical evidence from Bangladesh. International Development Planning Review 34(3): 217-240. doi:10.3828/idpr.2012.16 
Mata-Codesal, D. (2015). Ways of Staying Put in Ecuador: Social and Embodied Experiences of Mobility-Immobility Interactions. Journal of ethnic and migration studies, 41(14), 2274-2290. doi:10.1080/1369183X.2015.1053850

McCaughey, J.W., Daly, P., Mundir, I., Mahdi, S., Patt, A. (2018) Socio-economic consequences of post-disaster reconstruction in hazard-exposed areas. Nature Sustainability 1, 38-43. https://doi.org/10.1038/s41893-017-0002-z

Nadiruzzaman, M. and Wrathall, D. (2015). Participatory exclusion-Cyclone Sidr and its aftermath. Geoforum, 64: 196-204. https://doi.org/10.1016/j.geoforum.2015.06.026

Nawrotzki, R.J., DeWaard, J. (2018) Putting trapped populations into place: climate change and inter-district migration flows in Zambia. Regional Environmental Change 18, 533546. https://doi.org/10.1007/s10113-017-1224-3

Neumayer, E. and Plümper, T. (2007). The gendered nature of natural disasters: The impact of catastrophic events on the gender gap in life expectancy, 1981-2002. Annals of the Association of American Geographers 97(3): 551-566.

\section{https://doi.org/10.1111/j.1467-8306.2007.00563.x}

Oliver-Smith, A. (1996). Anthropological research on hazards and disasters. Annual review of anthropology 303-328. https://doi.org/10.1146/annurev.anthro.25.1.303

Oliver-Smith, A. (2016). Disaster risk reduction and applied anthropology. Annals of Anthropological Practice 40(1): 73-85. doi:10.1111/napa.12089

Oliver-Smith, A., Alcántara-Ayala, I., Burton, I., \& Lavell, A. (2017). The social construction of disaster risk: Seeking root causes. International Journal of Disaster Risk Reduction 22: 469-474. doi:https://doi.org/10.1016/j.ijdrr.2016.10.006

Parvin, G.A., Takahashi, F. and Shaw, R. (2008). Coastal hazards and community- 
coping methods in Bangladesh. Journal of Coastal Conservation 12(4): 181-193. https://doi.org/10.1007/s11852-009-0044-0

Paul, B.K. (2012). Factors affecting evacuation behavior: The case of 2007 Cyclone Sidr, Bangladesh. The Professional Geographer 64(3): 401-414. https://doi.org/10.1080/00330124.2011.609780

Paul, S.K. (2014). Determinants of evacuation response to cyclone warning in coastal areas of Bangladesh: A comparative study. Oriental Geographer 55(1-2): 5784.

Paul, B.K., Rashid, H., Islam, M.S. and Hunt, L.M. (2010). Cyclone evacuation in Bangladesh: tropical cyclones Gorky (1991) vs. Sidr (2007). Environmental Hazards 9(1): 89-101. https://doi.org/10.3763/ehaz.2010.SI04

Paul, B.K., Rahman, M.K. and Rakshit, B.C. (2011). Post-Cyclone Sidr illness patterns in coastal Bangladesh: an empirical study. Natural hazards 56(3): 841-852. https://doi.org/10.1007/s11069-010-9595-5

Pavlov, I. (1897). The work of the digestive glands. Thompson, W.H. (Trans.) London: Griffin. ISBN: 1521736154

Penning-Rowsell, E.C., Sultana, P. and Thompson, P.M. (2013). The 'last resort'? Population movement in response to climate-related hazards in Bangladesh. Environmental Science \& Policy 27(1): S44-S59. http://dx.doi.org/10.1016/j.envsci.2012.03.009

Piguet, E. (2013). From "primitive migration" to "climate refugees": The curious fate of the natural environment in migration studies. Annals of the Association of American Geographers 103(1): 148-162. doi: 10.1080/00045608.2012.696233 
Rashid, S. F., and Michaud, S. (2000). Female adolescents and their sexuality: Notions of honour, shame, purity and pollution during the floods. Disasters 24(1): 54-70. doi:10.1111/1467-7717.00131

Rivers, J. (1982). Women and children last: an essay on sex discrimination in disasters. Disasters 6(4): 256-267. https://doi.org/10.1111/j.1467-7717.1982.tb00548.x

Roy, C., Sarkar, S.K., Åberg, J. and Kovordányi, R. (2015). The current cyclone early warning system in Bangladesh: Providers' and receivers' views. International Journal of Disaster Risk Reduction 12: 285-299. https://doi.org/10.1016/j.ijdrr.2015.02.004

De Saussure, F. (2011). Course in general linguistics. In Meisel, P. and Saussy, H. (Eds.) Baskin, W. (Trans.). New York: Columbia University Press.

\section{ISBN: 9780231527958}

Stephens, N. M., Fryberg, S. A., Markus, H. R., and Hamedani, M. G. (2013). Who explains Hurricane Katrina and the Chilean Earthquake as an act of God? The experience of extreme hardship predicts religious meaning-making. Journal of Cross-Cultural Psychology 44(4): 606-619. https://doi.org/10.1177/0022022112454330

Tebboth, M. G. L., Conway, D., and Adger, W. N. (2019). Mobility endowment and entitlements mediate resilience in rural livelihood systems. Global Environmental Change 54: 172-183. doi:https://doi.org/10.1016/j.gloenvcha.2018.12.002

Thiede, B.C. and Brown, D.L. (2013). Hurricane Katrina: Who stayed and why? Population Research and Policy Review 32(6): 803-824. https://doi.org/10.1007/s11113-013-9302-9

Tschakert, P., Ellis, N. R., Anderson, C., Kelly, A., \& Obeng, J. (2019). One thousand ways to experience loss: A systematic analysis of climate-related intangible harm from around the world. Global Environmental Change 55: 58-72. doi:https://doi.org/10.1016/j.gloenvcha.2018.11.006 
UNFCCC (2013). Non-economic losses in the context of the work programme on loss and damage. Technical paper. Bonn: UNFCCC.

UNFCCC (2015). Adoption of the Paris Agreement. Draft decision-/CP.21. Geneva: United Nations Office at Geneva.

Watson, J.B. (1913). Psychology as the behaviorist views it. Psychological Review 20(2): 158-177. http://dx.doi.org/10.1037/h0074428

Watson, J.B. (1930). Behaviorism (Revised Ed.). London, USA and Toronto: W.W. Norton \& Company, Inc. ASIN: B0006AL49A

Watts, N., Adger, W. N., Ayeb-Karlsson, S., Bai, Y., Byass, P., Campbell-Lendrum, D., . . . Costello, A. (2017). The Lancet Countdown: tracking progress on health and climate change. The Lancet 389(10074): 1151-1164. ISSN 0140-6736 http://dx.doi.org/10.1016/S0140-6736(16)32124-9

Watts, N., Amann, M., Ayeb-Karlsson, S., Belesova, K., Bouley, T., Boykoff, M., .. . Costello, A. (2018). The Lancet Countdown on health and climate change: from 25 years of inaction to a global transformation for public health. The Lancet, 391(10120), 581-630. doi:https://doi.org/10.1016/S0140-6736(17)32464-9

Watts, N., Amann, M., Arnell, N., Ayeb-Karlsson, S., Belesova, K., Boykoff, M., . . . Montgomery, H. (2019). The 2019 report of The Lancet Countdown on health and climate change: ensuring that the health of a child born today is not defined by a changing climate. The Lancet. doi:https://doi.org/10.1016/S0140-6736(19)32596-6

White, G.F., Kates, R.W. and Burton, I. (2001). Knowing better and losing even more: the use of knowledge in hazards management. Global Environmental Change Part B: Environmental Hazards 3(3): 81-92. https://doi.org/10.3763/ehaz.2001.0308 